\title{
Camel Milk Value Chain in Kenya: A Review
}

\author{
Tura Isako (Corresponding author) \\ Beef Research Institute, Kenya Agricultural \& Livestock Research Organization (KALRO) \\ PO box 3840-20100, Nakuru, Kenya \\ Tel: +254-725949787 E-mail: tura.isako@kalro.org \\ Victoria Kimindu \\ Beef Research Institute, Kenya Agricultural \& Livestock Research Organization (KALRO) \\ PO box 3840-20100, Nakuru, Kenya \\ Tel: +254-740557935 E-mail: Victoria.kimindu@kalro.org
}

\begin{abstract}
The dromedary camel is considered an integral species of the arid and semi-arid lands (ASAL) in Kenya. It's adaptation to the climatic and geographical conditions of the ASAL had enabled the camel to be regarded as the most important animal source of food as well as source of transport, draught and cultural significance. Camel milk is to a great extent utilized in the ASAL at subsistence level, but also makes way to the peri-urban centres and ultimately to the capital city, where there is high demand for the product.

The main purpose of this review is to consolidate research done on camel milk value chain in Kenya, to establish the contribution of camel milk to the pastoral and national economy, to determine opportunities for investment by the county governments and private sectors as well as to recommend milk value chain upgrading strategies in a bid to increase livelihoods of pastoral communities and other actors involved in the camel milk value chain.

Keywords: camel milk, value chain, marketing, upgrading strategies
\end{abstract}

DOI: $10.7176 / \mathrm{JMCR} / 58-06$

Publication date:July $31^{\text {st }} 2019$

\section{Introduction}

The camel is one of the oldest animal domesticates occurring in two phenotypic forms as one humped (Dromedary) or two humped (Bacterian). The dromedaries (Camelus dromedarius) often occur in Africa and the Middle East while the Bacterian (Camelus Bactrianus) are found more often in Central Asia (Knoll and Burger, 2012). Being a multipurpose animal, it is globally kept for milk, meat, wool, transport, racing, tourism, agricultural work, and beauty contests (Faye, 2015). Of the projected world population, 31.1 million are believed to be one-humped dromedary camels (Camelus dromedarius) and 3.7 million two-humped (Camelus bactrianus). Approximately 20.1 million dromedaries, representing two thirds of the world's camel population, are in in North East Africa, i.e. Somalia, Sudan, Ethiopia and Kenya.

Camels also play an important role in the pastoral society as they offer transport to people and cargo, plough farms, de-silt dams, and are an important requirement in ceremonies such as marriage, burials, and religious events and in conflict resolution. A few camels are found scattered across the country mainly for touristic amusement through trekking safaris and camel racing (CAMASEPRO, 2012).

1.1 Camel population in Kenya and the world

According to Food and Agriculture Organization (FAO), 2019, the global estimate of camels in 2017 was 34.8 million, of which 30.1 million are found in Africa and 4.7 million in Asia. Kenya has the fourth largest camel herd in the world (Table 1) estimated at 3,338,757 after Chad, Somalia and Sudan. 
Table 1. Estimated camel populations of Africa and the world in 2017

\begin{tabular}{||l|c|l|c||}
\hline \hline \multicolumn{5}{|c|}{ Country } & \multicolumn{3}{|c||}{ Africa } & Camel Population \\
\hline Chad & $7,285,309$ & Nigeria & 282,000 \\
\hline Somalia & $7,222,181$ & Tunisia & 237,005 \\
\hline Sudan & $4,849,003$ & Egypt & 149,224 \\
\hline Kenya & $3,338,757$ & Western Sahara & 111,329 \\
\hline Niger & $1,788,149$ & Djibouti & 70,965 \\
\hline Mauritania & $1,479,648$ & Libya & 64,469 \\
\hline Ethiopia & $1,210,663$ & Morocco & 59,000 \\
\hline Mali & $1,192,900$ & Burkina Faso & 19,475 \\
\hline Algeria & 381,882 & Senegal & 4,765 \\
\hline Eritrea & 379,189 & Namibia & 90 \\
\hline \multicolumn{5}{|c||}{ Other Areas } & $7,19,196$ \\
\hline Mongolia & 434,096 & Iraq & 66,390 \\
\hline India & 325,155 & Syria & 40,843 \\
\hline China, & 323,000 & Qatar & 17,685 \\
\hline Oman & 262,870 & Uzbekistan & 14,322 \\
\hline Kazakhstan & 193,124 & Jordan & 9,389 \\
\hline Afghanistan & 172,000 & Kuwait & Europe \\
\hline Iran & 141,052 & FAO, 2019 & \\
\hline \hline
\end{tabular}

Source: FAO, 2019

\subsection{Camels in the ASAL of Kenya}

The dromedary camel in a Kenyan context is considered an integral species of the arid and semi-arid lands (ASAL), an eco-system characterized by low and sparse rainfall ranging between $150 \mathrm{~mm}$ and $550 \mathrm{~mm}$ annually, high temperatures throughout the year and with high rates of evapo-transpiration (GoK, 2017).

The ASAL occupies approximately $89 \%$ of the country's landmass, hosting about $36 \%$ of the human population, $70 \%$ of livestock and $90 \%$ of wildlife (GoK, 2017). An estimated $70 \%$ of cattle, $87 \%$ of sheep, $91 \%$ of goats and $100 \%$ of camels of the national livestock population are found in ASALs (Behnke and Muthami, 2011). Pastoralism, agro-pastoralism and dry-land agriculture are the key livelihood strategies adapted to climate conditions in ASALs.

Most of the camels in Kenya are found in the north and north eastern counties of Turkana, Baringo, Marsabit, Wajir, Mandera, Isiolo, Garissa and Tana River where they are mostly kept by pastoral communities namely Somali, Gabbra, Rendille and Turkana (Musinga et al, 2008). In Kenya, camel population density increases with aridity as portrayed in Figure 1. 


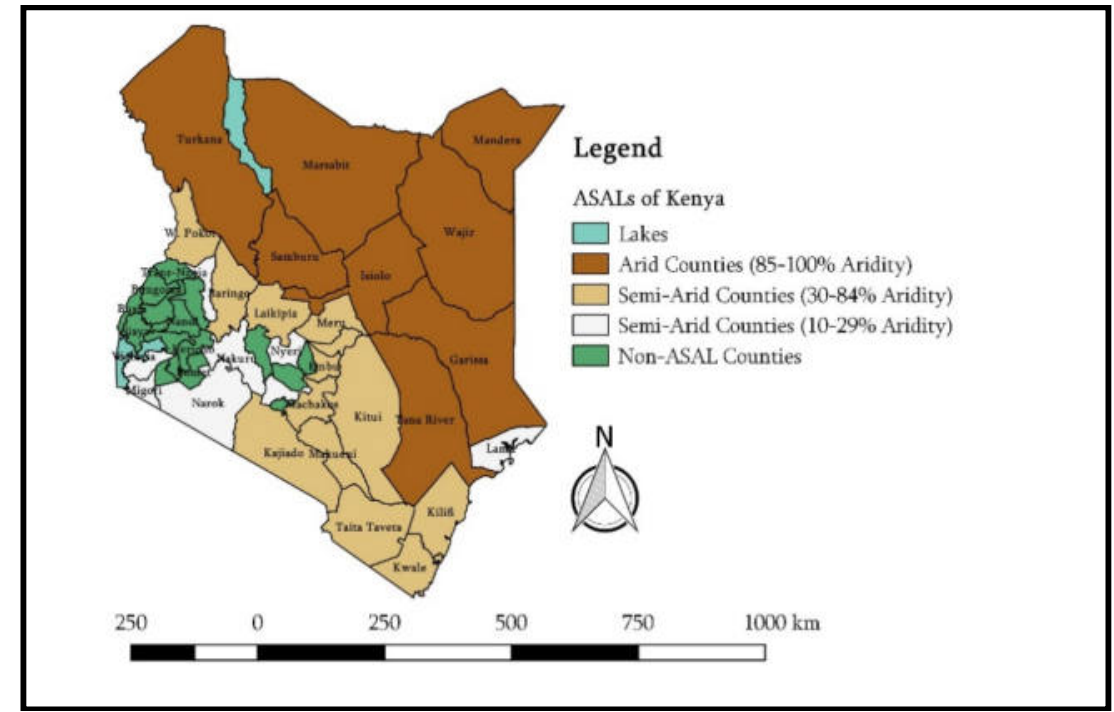

Figure 1: Map of Arid and Semi-Arid Lands of Kenya

Source: Statistics derived from Ministry of Devolution and ASAL areas, 2017

As illustrated in Figure 2. the counties leading with the highest camel populations are Mandera with 1,016,970 (Mandera CG, 2018), Turkana with 832,462 (Turkana CG, 2013), Wajir with 533,651 (Wajir CG, 2015), Garissa with 486,000 (Garissa CG, 2018) and Marsabit with 217,360 (Marsabit CG, 2018). All these counties are predominantly arid ecological zones. They are distantly followed by Samburu with 60,000 (Samburu CG, 2013), Isiolo with 40,460 (Musinga et al, 2008), West Pokot with 35,271 (West Pokot CG, 2018), Baringo with 10,189 (Baringo CG, 2013) and Laikipia with 9800 camels (Laikipia CG, 2018). These counties fall between arid and semi-arid zones with $30-84 \%$ aridity.

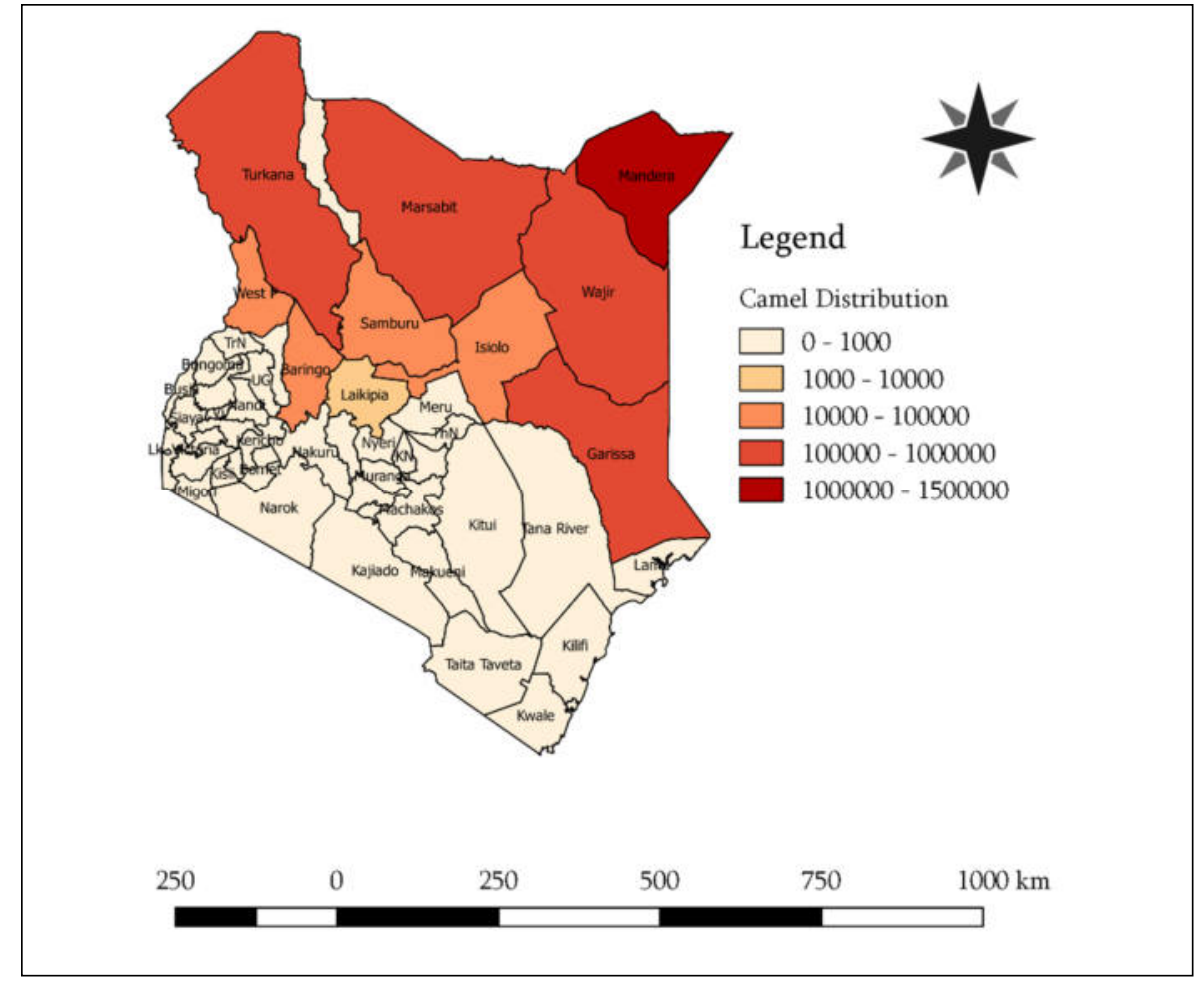

Figure 2: Map of Camel Population Distribution in Kenya

Source: Compiled from various County Government integrated development plans 
Camels are able to survive in such environments due to an array of excellent anatomical and physiological adaptations that allow them to withstand long periods of time without water without any adverse effects (Khan et al, 2003). These communities keep camels for food security by the provision of milk and meat, as well as hides.

1.2 Camels in the peri-urban areas

Camel rearing within peri-urban areas for the purpose of supplying milk and meat to the increasing human population in the towns is emerging as a new production system (Agriconsortium, 2003). Due to rural-urban migration and a great demand for camel milk in urban areas, camel milk production has greatly increased in periurban centres such as Kajiado (Muloi, 2018), Mt. Marsabit (Tura and Walaga, 2015) and Isiolo's central division (Noor, 2013). Adoption of camels by non-camel keeping communities is a trend observed across the peri-urban centers of the North. Furthermore, camels have shifted further south gaining importance in have been successfully introduced in Kajiado, Samburu, Meru, Laikipia, West Pokot, Kilifi, Kitui, Mwingi, and Narok; areas where until recently cattle were the only large domestic herbivore species kept. The shift has been seen as an adaptability response to climate change, as a means to build climate resilience since camels can survive severe droughts and continue to offer food security and economy in dry periods better than other classes of livestock (Hülsebusch and Kaufmann, 2002). Herren, 1990 reported during prolonged droughts, milk production in cattle and goats' ceased at higher proportions of $52 \%$ and $75 \%$, respectively than camels $22 \%$. Furthermore, while the national livestock population has been on a decline in the past two decades for reasons attributed to climate change as evidenced by more frequent droughts (UNDP, 2005), decline in long-season rainfall and the significant warming in temperature (USAID, 2010), the camel population has somewhat stabilized in the past decade (Figure 3). This has been attributed to the camels better adaptation to the changing climate (Hülsebusch and Kaufmann 2002).

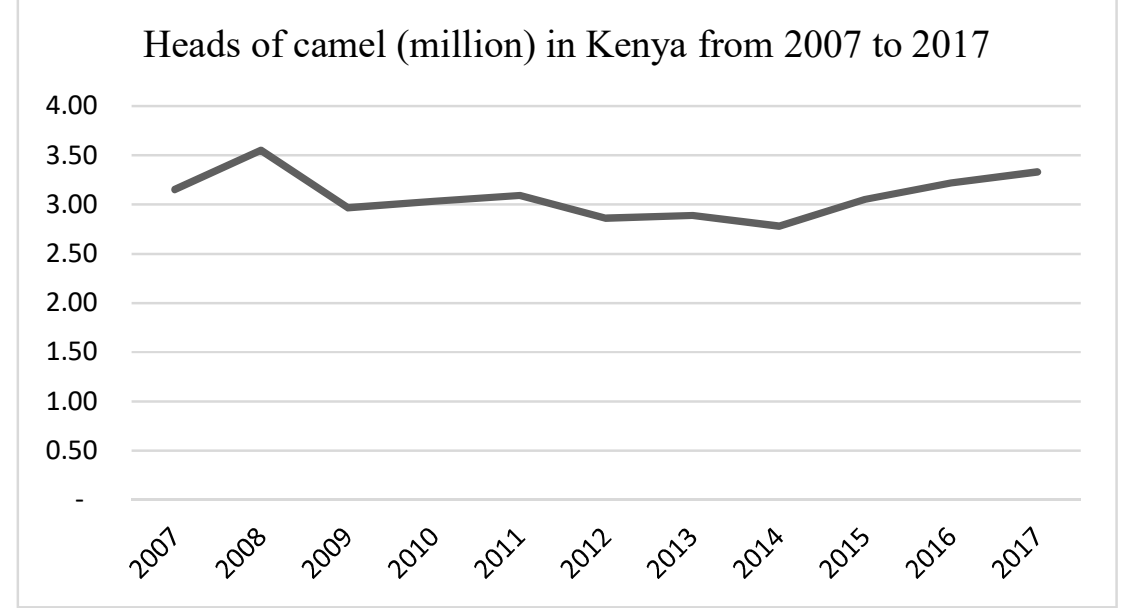

Figure 3: Camel population trends in Kenya between 1997 and 2007

Source: FAO, 2019

\subsection{Camel milk Production in Kenya}

Milk in Kenya is predominantly produced from cattle, camel and goats which support approximately 1.8 million rural households and additional 700,000 jobs along the dairy value chain (GoK, 2019). Due to climatic variability in the ASAL, a majority of northern pastoralists pursue camel husbandry with constant movement in search of better pasture and water (Farah et al, 2004). Camel milk production therefore varies greatly from place to place depending on feed quality and quantity, water availability, breed, milking frequency, disease status, physiological state of the camel (Simpkin et al., 1996). For example, GoK (2019) reported that the Somali and Pakistani camel breeds are higher milk producers than Rendille/Gabra and Turkana breeds and are more popular for dairy production in the country. Simpkin (1998) reported that during a lactation of 10 to 12 months, the Somali adult female camels produces a daily average yield of 5 to $8 \mathrm{~kg}$; the Rendille/Gabra breed 3 to $4 \mathrm{~kg}$ and the Turkana camel breed is $2 \mathrm{~kg}$ to $3 \mathrm{~kg}$ per day.

According to FAO, 2019, Kenya was the second highest camel milk producer in 2017, production reaching 876,224 tonnes after Somalia with 953,673 tonnes (Table 2). It represented $18.40 \%$ of total milk produced in Kenya in 2017 , valued at KES 87.6 billion, behind cow milk which was leading at $74.83 \%$ but ahead of goat and sheep milk at $5.40 \%$ and $1.41 \%$ respectively (Figure 4 ). 
Table 2: Global leaders of fresh camel milk producers in 2017

\begin{tabular}{|c|c|c|c|}
\hline Country & Camel milk (tonnes) & Country & Camel milk (tonnes) \\
\hline Somalia & 953,673 & $\begin{array}{c}\text { China, } \\
\text { mainland }\end{array}$ & 14,559 \\
\hline Kenya & 876,224 & Algeria & 14,004 \\
\hline Mali & 300,000 & Yemen & 13,431 \\
\hline Ethiopia & 171,706 & Eritrea & 12,169 \\
\hline Saudi Arabia & 134,266 & Morocco & 8,750 \\
\hline Niger & 107,745 & Qatar & 8,590 \\
\hline Chad & 64,634 & India & 8,107 \\
\hline Sudan & 60,897 & Afghanistan & 6,824 \\
\hline UAE & 54,024 & Djibouti & 6,043 \\
\hline Mauritania & 25,000 & Mongolia & 5,900 \\
\hline
\end{tabular}

Source: FAO, 2019

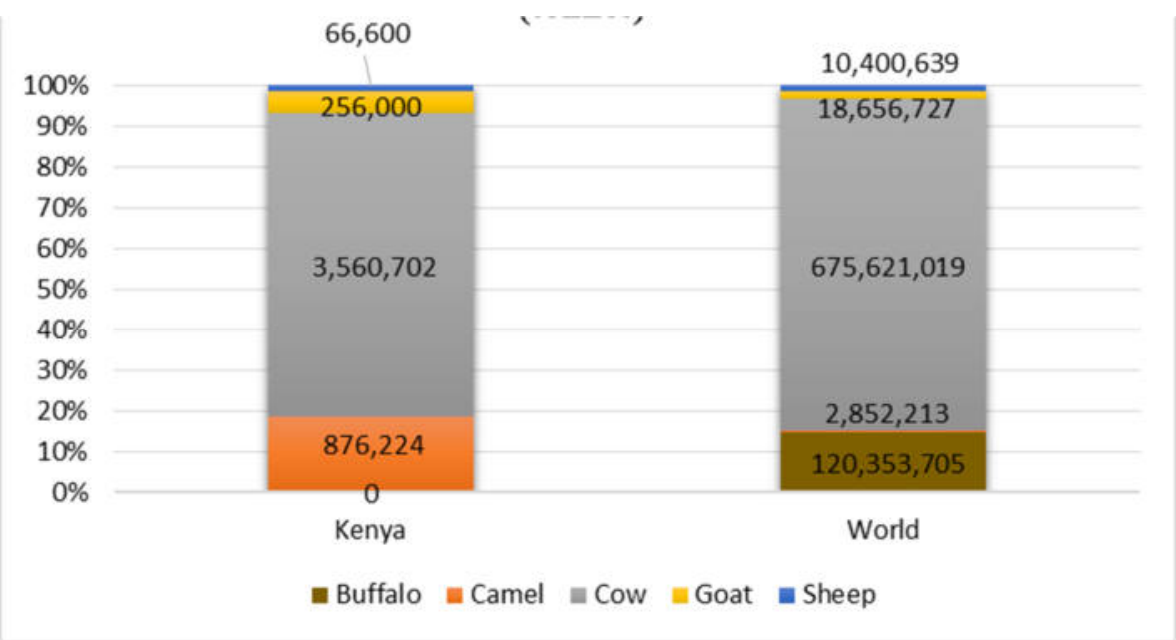

Figure 4. Global and Kenyan milk production across species in 2017

Source: FAOSTAT, 2019

Camel milk production in Kenya has been on a steady incline for the past 2 decades (Figure 5) and this has been attributed to the developing of camel milk market integration, specifically with the urbanization of populations formerly living in pastoral areas (Muloi et al, 2018).

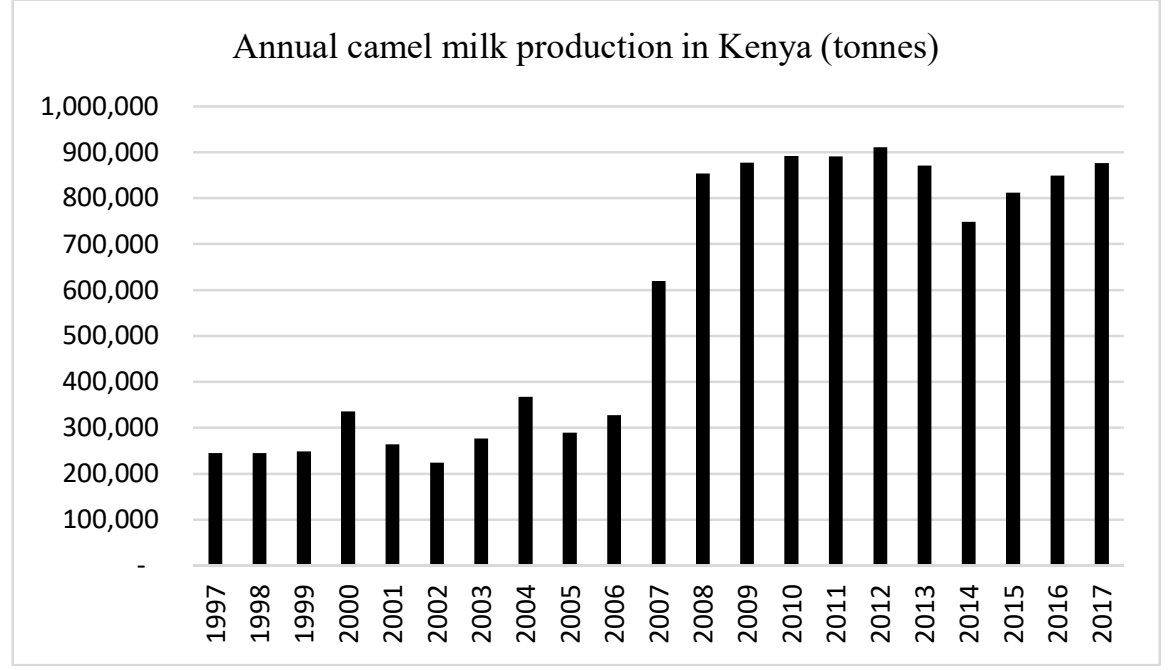

Figure 5. Production trends of camel milk in Kenya

Source: FAO, 2019 
The informal camel milk trade to supply urban consumers has become an important source of income for camel keepers (CAMASEPRO, 2008). Of equal importance has been the aggressive marketing of the nutritional properties of camel milk by camel milk processors and some county governments in the ASALs (Turkana CG, 2018).

\subsection{Potential of camel milk and its benefits to the ASAL}

Camel milk is to a great extent utilized in the north and north eastern counties at subsistence level. In dry seasons and times of drought when occasioned with scarcity of milk from cattle, sheep and goats, the camel contributes to the nutrient uptake of the pastoralists by up to 50\% (Farah \& Fischer, 2004).

The gross production value of camel milk in Kenya stands at US\$ 450.1 (Figure 6.) which is 2.5 times higher than that of sugar cane, 4.7 times higher than green coffee, 7.9 times higher than indigenous chicken and 115 times greater than lint cotton.

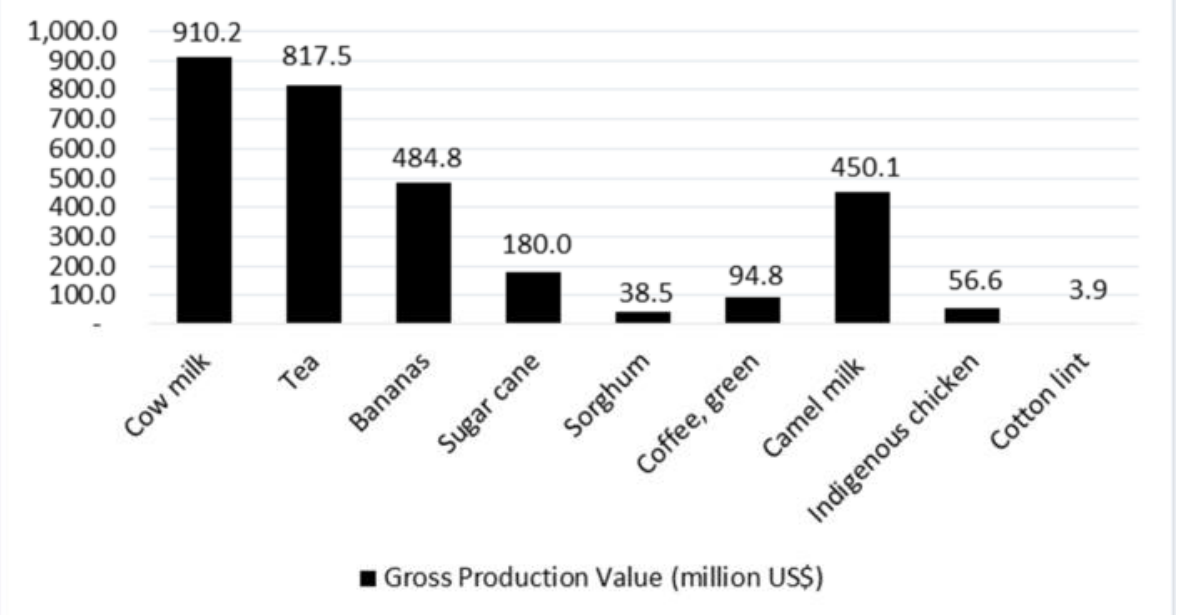

Figure 6: Gross production value of camel milk and other commodities in Kenya in 2017 Source: FAO, 2019

However, the contribution of camels to the socioeconomic welfare of the pastoralists in Kenya has been unnoticed by a combination of dynamics that tend to underestimate their true value (Farah et al, 2004). Firstly, camel population estimates are usually inaccurate due to lack of regular census. The 2019 national household census will attempt to reveal the camel distribution and population across the country. Secondly, camel products and in particular milk which rarely enters the formal economy tends to be grossly underestimated. Thirdly, little consideration has been given to camel improvements for many years when planning national development. For example, out of the 29 counties confirmed as ASAL, only 7 arid counties had made mid-term plans for improving the productivity and products of the camel (Table 3 ).

Table 3: Provisions for the camel in the Arid Counties integrated development plans (CIDP) 2018-2022.

\begin{tabular}{|l|l|l|l|l|}
\hline & County & $\begin{array}{l}\text { Camel } \\
\text { numbers }\end{array}$ & CIDP objectives specifically targeting the camel & Source \\
\hline 1 & Turkana & 832,462 & $\begin{array}{l}\text { Promote camel rearing } \\
\text { Revamp marketing of camel products }\end{array}$ & Turkana CG, 2018 \\
\hline 2 & Marsabit & 217,360 & Support Moyale Camel Dairy Cooperative & Marsabit CG, 2018 \\
\hline 3 & Wajir & 533,651 & Camel breeds to be introduced in all sub counties & Wajir CG, 2015 \\
\hline 4 & Mandera & $1,016,970$ & - & Mandera CG, 2014 \\
\hline 5 & Samburu & Undeclared & Establish land in the lower midlands for camel rearing & Samburu CG, 2018 \\
\hline 6 & Isiolo & Undeclared & $\begin{array}{l}\text { Improve camel breeds } \\
\text { Support four camel milk marketing cooperatives } \\
\text { Demarcate land for pasture, fodder and disease free zones }\end{array}$ & Isiolo CG, 2018 \\
\hline 7 & Garissa & 486,000 & $\begin{array}{l}\text { Increase yearly camel milk production by } \\
\text { 0.5 ltr/she-camel } \\
\text { Fully operationalize Garissa, Korakora and Daadab } \\
\text { camel dairies }\end{array}$ & Garissa CG, 2018 \\
\hline 8 & $\begin{array}{l}\text { Tana } \\
\text { River }\end{array}$ & undeclared & $\begin{array}{l}\text { Purchased \& distributed 120 camels to most vulnerable } \\
\text { to enhance drought preparedness }\end{array}$ & Tana River CG, 2018 \\
\hline
\end{tabular}

Source: Various county integrated development plans 


\subsection{Nutritional potential of camel milk}

In a meta-analysis study (1905-2006) done by Zibaee et al, 2015, camel milk was examined and compared with other milk in six manuscripts (Kanuspayeva et al, 2009, Khaskheli et al, 2005, Omar and Hamad, 2010, Abdoun et al, 2007, Shamsia 2009 and Yagil 1982). Camel milk components were reported to average as follows: protein $3.1 \%$; fat $3.5 \%$; lactose $4.4 \%$; ash $0.79 \%$, and water content averaging at $88.1 \%$ which is similar to that of human milk. Camel milk is also reported to have therapeutic qualities, citing that it can be used in treatment of Rota viral diarrhea (Mona, 2010, Yagil, 2013), cow milk allergy (Ehlayel, 2011) autism (Shabo and Yagil, 2005, Al Ayadhi, 2013) as well as metabolic and autoimmune diseases, hepatitis, tuberculosis, diabetes, liver cirrhosis and rickets (Zibaee et al, 2015).

\subsection{Camel milk marketing and National value chains analysis}

The camel dairy value chain map is summarized in Figure 7. Camel milk marketing system in Kenya is largely informal, featuring traders acting as conduits between producers, bulking agents, processors and consumers (Muloi et al, 2018). The available formal marketing is through dairy cooperatives and commercial processors such as the Vital Camel Milk limited (Vital brand) and Ngamia Milk suppliers (White gold brand) both found in Nanyuki, Laikipia County that pasteurizes packages and maintains cold storage and distribution of camel milk up to distant retail outlets.

There are five main routes to the market as established by Muloi et al, 2018 and Sikuku, 2016):

i. Consumption within a herder's household as well as calf milk (unestablished volumes with seasonal variation)

ii. Consumption in rural households and restaurants (consumed fresh, fermented or used for making tea),

iii. Consumption in urban markets including Nairobi’s Eastleigh suburb, Nakuru, Mombasa, Kisumu,

iv. Consumption at high-end health markets.

v. Exports.

Camel milk marketing studies carried out in Isiolo (Nyamori and Kagunyu, 2005; Noor et al 2013; Elhadi and Wasonga, 2015; Muloi et al, 2018), Garissa (Bruntse, 2004), Kajiado (Muloi et al, 2018) indicate that the main urban market for camel milk is Eastleigh in Nairobi, a suburb largely inhabited by the Somali community.

\subsection{County status of camel milk value chains}

3.1.1. Isiolo

Muloi et al, 2018 established that about 5\% of pastoralists owned herds above 50 camels, $80 \%$ owned $50-100$ camels and 15\% owned herds below 50 camels. Mwaura et al, 2015 identified that the milk traders in this chain were predominantly women organized in marketing cooperatives such as Anolei Camel Milk Marketing Cooperative Society, Tawakal Self-Help Women's Group and Defee Self-Help Women's Group. These traders purchase milk from the pastoralists, in 20 litre plastic containers and deliver to bulking Centre that assess the quality of milk, provide cooling facilities, market information, training credit facilities and bargaining power over the sale price of camel milk to the terminal market in Nairobi. Tawakal Cooperative Society for instance has successfully added value to camel milk and is processing yoghurt and 'susa', a traditional fermented sour milk.

Upon arrival in Nairobi's Eastleigh market, $85 \%$ of the milk delivered is traders sold directly to end users (household level), to milk bars, to small and medium restaurants and to three and four star hotels, while $10 \%$ exported to Kampala Uganda; 3\% is sent to Kakuma in Northern Kenya, and 2\% is consumed in numerous local towns such as Nakuru, Eldoret, Kisumu and Mombasa (Muloi et al, 2018)

AU-IBAR, 2017 estimated that the Isiolo - Nairobi camel milk trade created a monthly gross turnover of up to KES. 10.58 million, and about $94 \%$ of this was due to the demand for camel milk in the Nairobi terminal market. This demand for hygienically produced camel milk in urban areas outstrips supply and is likely to continue to grow. Provision of veterinary services in the rangelands is limited but the pastoralists mostly depend on nongovernmental organizations and community animal health workers for provision of health services. However, pastoral communities have also developed immense indigenous knowledge in managing camel diseases, albeit with varying degrees of success.

3.1.2. Kajiado

Muloi et al., 2018 reported that about $20 \%$ of pastoralists owned herds above 50 camels, $65 \%$ owned $50-100$ camels and 15\% owned herds below 50 camels. Milk traders reported transporting milk using off-road vehicles and motorbikes to collection centres in Bisil and Kajiado towns. The milk is then transported in bulk to Eastleigh market where milk traders distribute $80 \%$ of the milk to end user customers; $10 \%$ to small and medium restaurants; $7 \%$ to large hotels and 3\% to milk bars. In this value chain, no milk is exported to other countries or transported to areas outside Nairobi.

3.1.3. Garissa

In Garissa, report by Bruntse (2004) indicates that there is substantial amount of milk from the upland (about 1200 1/day - camels, cattle and goats) that is marketed right in Garissa town mainly by organized and registered women groups. The chains are reported to be similar to those observed in Isiolo where the market chain involves the 
producer sellers, middlemen and consumers (Musinga, et al, 2008). Other stakeholders in the milk marketing chain at Garissa are the transporters, local authorities (obtain cess) and the public health department. Bruntse (2004) report further indicates that at least 1000 liters of camel milk are transported from Bangalle in Tana River for sale at Eastleigh, Nairobi on buses and matatus.

3.1.4. Mandera

In Mandera, the chain is more organized with majority of the sellers being intermediaries between the producers and consumers. The intermediaries, who are predominantly women affiliated to individual women groups under the umbrella of Mandera Milk Sellers Women Group, buy milk from the pastoralists and deliver to towns by vehicles. The milk marketing chain in Mandera could be summarized as follows: producer sellers - primary milk collector (mainly female) - milk transporter (male) - secondary milk collector and seller (mainly women groups in the town) - consumers in the town. On the average, each producer markets 30 liters of camel milk daily (Wayua et al. 2004). According to Mandera County Government (2018), camel milk production in 2015 was 530,729 litres and was valued at KES. 53,072,900

3.1.5. Marsabit

In Marsabit town, most of the milk is sold in the open-air market (Mulinge et al. 2001). Hawkers or producers themselves deliver the fresh smoked or non-smoked milk to the market. There appeared to be few middlemen in Marsabit market trading in the dairy products. Women walk on foot from as far as from Karare (20 km) carrying small amounts of milk to the open-air market every morning. In Moyale, most of the milk handled in the open-air market is sour, fresh milk being delivered directly to consumers by producer sellers (Mulinge et al. 2001).

According to Tura \& Walaga 2015, the peri-urban area of Mt. Marsabit has over 900 camels kept between households and primary schools. The Somali breed camel consists of $93 \%$ of camels kept on the mountain followed by crosses of Rendille/Gabbra x Somali 6\% and Rendille breed 1\%. Adopters and indigenous keepers form $91 \%$ and $1 \%$ of camel keepers respectively. The main challenges facing camel production here were identified as; slippery ground during the rainy season, limited water sources, high tick load, high infestation of biting flies, limited land size and crop- camel conflict. Due to smaller land size on Mount Marsabit keeping large herds can be destructive to the environment. It is recommended milking herds of 15-20 camels be integrated with other livestock species in private land/ranch of about 250 acres. Similarly, capacity building of the camel adopters on camel production and husbandry.

3.1.6. Nanyuki Camel dairy processor (Laikipia County)

Muloi et al., 2018 reported that in the Nanyuki camel milk chains, ranching is the main form of camel keeping, where camels are grazed in open grasslands and in the evening kept into enclosed structures. This system is characterised by a higher quality of veterinary care and management practices. $50 \%$ of farms supplying milk in this chain are reported to produce $50 \mathrm{~L}$ of milk per day. The processing company reported to work directly with farmers, without relying on middlemen. Whole pasteurized milk was reported as the main processed product at $60 \%$ of the total processed milk, while $25 \%$ was low fat boiled milk, and $7 \%$ yoghurt. Fermented milk and other milk products made up the remaining $5 \%$. The company estimated that approximately $85 \%$ of the processed camel milk products were sold to large and medium sized supermarket outlets in Nairobi. On the other hand, 10\% of the processed products were sold to other towns in Kenya, and 5\% exported to regional and international markets.

3.1.7. Elgeyo Marakwet

Lapkeiyet self help group in Kerio Valley, a predominantly cattle-keeping region was first introduced to camels (a bull and 4 females) in 2005 amidst much reservation from the community, citing breach of culture and possible spurring of inseurity from camel bandits (The Standard, 2018). In 2018 the camels were more than 100. The group supplies more than 100 litres of milk to Eldoret town at Sh100 to Sh120 per litre which is double what a litre of cow milk retails for (The Standard, 2018). The purchase of a milk coolant plant to preserve the camel milk in wet seasons has reduced milk losses.

\subsection{Seasonality of the milk and prices}

In Isiolo district, the study by Nyamori and Kagunyu (2005) revealed that more than $90 \%$ of traders dealt in camel milk during the dry season unlike in the wet season when both cattle and camel milk were available. At Laisamis in Marsabit district, both households and traders sold goat and sheep milk during the dry season since cattle and also camels were in the satellite camps and hence limited milk supply within the settlements. The price of a liter of camel milk mostly ranges from Ksh. 20 to 80 depending on the season, location and the stage in the marketing chain. The village level prices of camel milk in Mandera for example are Ksh.5 per $400 \mathrm{ml}$ cup, whereas in the town the price is Ksh. 15 (Wayua et al. 2004). Unconfirmed reports indicate that the camel milk being marketed at Eastleigh, Nairobi by Vital Camel Milk Dairy as health food is fetching over Ksh. 300/liter. In both Isiolo and Marsabit districts, the price of milk increased by an average of $25 \%$ in the dry season due to low milk supply and relatively higher demand (Nyamori and Kagunyu 2005). 


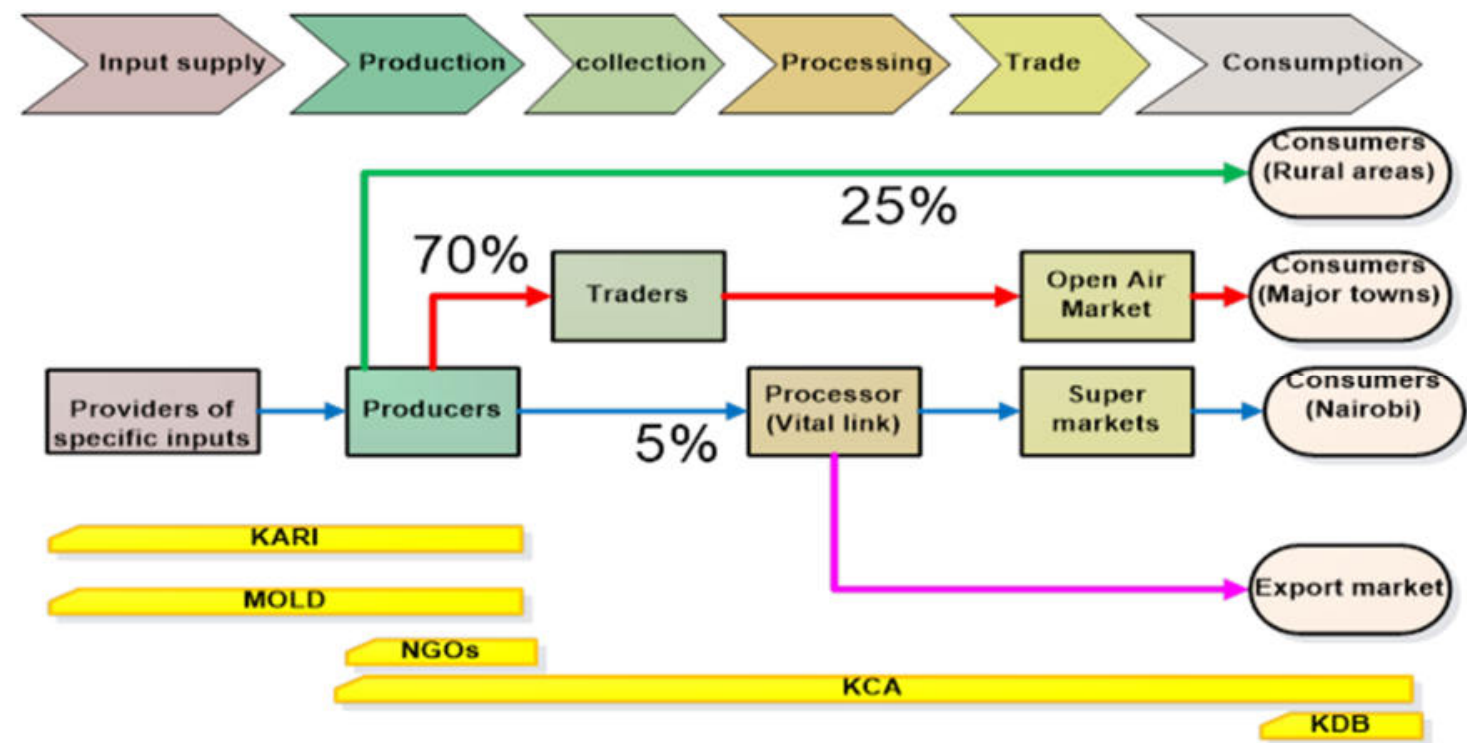

Figure 7: The Camel dairy value chain map

Source: Tura et al, 2011

\subsection{Challenges}

The review identified six key constraints in camel milk value chain that were in agreement with the findings of national milk value chain analysis conducted in 2011 as:

i. Inadequate market infrastructure

ii. Limited processing facilities and poor milk handling along the value chain

The environment in which camels are reared is characterized with dust/mud and high water scarcity. Often pastoralists use camel urine to 'clean' their hands and the milking containers when milking. Use of smoke to disinfect milking containers is a common practice among camel keeping communities which hinders milk marketing because this practice renders the milk smelly which is not acceptable to a cross section of consumers. Similarly, the lack of cooling facilities is a major impediment.

Camel milk is commonly stored in traditional containers that are difficult to clean. Plastic containers are the most popular container material used to transport camel milk are equally difficult to clean and are easily get contaminated, leading to spoilage of camel milk. Donkeys and old vehicles are the most common means of transporting camel milk from production areas to the destination urban centres.

iii. Lack of organized market channels

Difficulties in aggregating the milk volumes required for the market and long distances to the markets and poor infrastructure are major challenges in marketing camel milk.

iv. Limited access to credit

v. Limited technological innovations and value addition

vi. Poor linages along the value chain.

3.4 Opportunities

Camel milk is one of the main product of camel with a high interest for local population in ASALs for the main reason that it is self-consumed within the producing rural community and thus, contributes to the food security in the ASALs. On the other hand, the presence of a growing demand for camel milk from the urbanized population in those areas and thus a growing market opportunity. However, as the camel milk is still not widely integrated into a number of county government development plans, the product risks being ignored. Opportunities lie in the camel being resistant to severe droughts and provision of milk throughout the year unlike cattle. Access to good transport infrastructure and proximity to major markets which offer higher price is a key opportunity. Enhancing linkages between producers, transporters and traders will strengthen quality assurance from farm level through use of cold chain. Improvement of camel milk market facilities, value addition and improved packaging to appeal to non- camel keeper's consumers is another opportunity. The deliberate provision of adequate capacity building on camel milk hygiene and handling practices across the rural communities as well as the diversification of the camel milk value chain portfolio are potential opportunities. Cooperative development and oriented policies are required to enable easy trade in this sub sector and others to address the identified barriers. 


\subsection{National upgrading strategy}

The national value chain analysis is purposed to determine facilitation of the chain development process, strengthen private business linkages, foster public private partnership, finance services in value chains, introduce social, ecological and product quality standards, improve the business environment of value chains, monitor and manage impact as well as determine the camel milk chain upgrading strategy

The upgrading strategy developed by stakeholders/actors in the camel milk value chain organized by KARI Garissa in 2011 (Tura et al, 2011) recommended Market penetration of camel milk in the local and export markets. This can be achieved through enhancing quality in the camel milk marketing to urban consumers and export and this will look into the following: camel milk borne diseases, capacity building for actors on milk handling hygiene, enhanced milk production (feeds, supplementation, disease control, camel breed selection), camel milk end market analysis and camel milk policy framework.

\subsection{Stakeholders in the camel milk value chain}

Stakeholders in the camel milk value chain (Table 4) include camel producers in the northern and southern rangelands, camel traders associations, camel milk processors (women led self-help groups and industry), camel butchers association, national and county government officers in the livestock, veterinary and public health departments, Kenya Agricultural and Livestock Research Organization (KALRO), Kenya Livestock Marketing Council and the Kenya Camel Association as well as numerous non-governmental organizations.

Through the collaborative partnerships of various stakeholders, commercialization of the camel milk value chain has been enhanced. For instance, the coming together of women traders in self-help groups has facilitated the organized financing of the camel milk enterprises, providing enough capital to purchase milk from producers and transport the same to final market destinations (BDA, 2018). The provision of aluminum and mazzi cans and cold storage to various women-led self-help groups in the Northern ASALs has safeguarded the quality and shelf life of camel milk, enabling it to reach the final markets in good stable condition (USAID, 2019). The provision of organized camel milk transport networks for traders has equally boosted the commercialization of the product, enabling the reliable delivery of camel milk to final markets (Muloi et al, 2018).

Table 4. Activities of the main stakeholders in the camel milk value chain

\begin{tabular}{|c|c|c|c|c|}
\hline Stakeholder & Location & Key Activity & Period & Impact \\
\hline $\begin{array}{l}\text { Government of } \\
\text { Kenya } \\
(\mathrm{NMG}, 2013)\end{array}$ & ASALs & $\begin{array}{l}\text { Distribute } 75 \text { camels to self- } \\
\text { help groups and schools and } \\
\text { extension services }\end{array}$ & $\begin{array}{l}2013- \\
2014\end{array}$ & $\begin{array}{l}\text { Boost camel population } \\
\text { Enhance food security } \\
\text { Mitigate effects of climate } \\
\text { change }\end{array}$ \\
\hline $\begin{array}{l}\text { Kenya Agricultural } \\
\& \quad \text { Livestock } \\
\text { Research } \\
\text { Organization } \\
\text { (KALRO) } \\
\text { (KALRO, 2017) }\end{array}$ & National & $\begin{array}{l}\text { Generate and promote } \\
\text { technologies, strategies and } \\
\text { innovations for demand } \\
\text { driven camel product value } \\
\text { chain }\end{array}$ & $\begin{array}{l}1999- \\
2003 \\
2009- \\
2014 \\
2018- \\
2022\end{array}$ & $\begin{array}{l}\text { Characterized camel } \\
\text { breeds. } \\
\text { Improved camel } \\
\text { productivity and welfare } \\
\text { Enhanced livelihoods of } \\
\text { camel keepers. } \\
\text { Products value addition }\end{array}$ \\
\hline $\begin{array}{l}\text { Kenya Livestock } \\
\text { Marketing Council } \\
(\text { KLMC) } \\
\text { In collaboration } \\
\text { with other } \\
\text { stakeholders } \\
(\text { KLMC, 2000) }\end{array}$ & National & $\begin{array}{l}\text { Provide reliable market } \\
\text { information to producers } \\
\text { and traders } \\
\text { generates market } \\
\text { information system linking } \\
\text { producers and traders to the } \\
\text { markets (prices and } \\
\text { volume) } \\
\text { capacity building on value } \\
\text { addition of milk, hides and } \\
\text { skins } \\
\text { actively participate in the } \\
\text { co-management of markets }\end{array}$ & $\begin{array}{l}2000 \text { to } \\
\text { date }\end{array}$ & $\begin{array}{l}\text { Enhanced market access for } \\
\text { livestock producers and } \\
\text { traders } \\
\text { Provision of reliable and } \\
\text { timely market information } \\
\text { Improved livelihoods of } \\
\text { livestock keepers in the } \\
\text { drylands }\end{array}$ \\
\hline $\begin{array}{l}\text { Kenya Camel } \\
\text { Association } \\
(\mathrm{KCA}, 2018)\end{array}$ & National & $\begin{array}{l}\text { Capacity building of camel } \\
\text { production and product } \\
\text { value addition through field } \\
\text { days }\end{array}$ & annually & $\begin{array}{lr}\text { Improved } & \text { camel } \\
\text { management } & \text { and } \\
\text { productivity } & \end{array}$ \\
\hline $\begin{array}{l}\text { Kenya Bureau of } \\
\text { Standards (KEBS) } \\
\text { (KEBS, 2006) }\end{array}$ & National & $\begin{array}{l}\text { Provision of specification } \\
\text { for raw whole, pasteurized } \\
\text { and fermented camel milk }\end{array}$ & $\begin{array}{l}2006- \\
2017\end{array}$ & $\begin{array}{ll}\text { Enforcement of product } \\
\text { conformity } \\
\text { Enhanced } \\
\text { confidence }\end{array}$ \\
\hline
\end{tabular}




\begin{tabular}{|c|c|c|c|c|}
\hline & & & & Enhanced trade \\
\hline $\begin{array}{l}\text { ILRI } \\
\text { (ILRI, 2018) }\end{array}$ & $\begin{array}{lll}\text { ASALs in } & \text { Northern } \\
\text { Kenya and } & \text { Southern } \\
\text { Ethiopia } & & \end{array}$ & $\begin{array}{l}\text { Research across the camel } \\
\text { meat and milk value chains }\end{array}$ & ongoing & $\begin{array}{l}\text { Reduced poverty, enhanced } \\
\text { food and nutrition security, } \\
\text { improved natural resources } \\
\text { and ecosystem services. }\end{array}$ \\
\hline $\begin{array}{l}\text { Kenya Investment } \\
\text { Authority } \\
(\mathrm{KIA}, 2004)\end{array}$ & National & $\begin{array}{l}\text { To strengthen awareness of } \\
\text { investment potential in the } \\
\text { camel milk value chain }\end{array}$ & $\begin{array}{l}2004 \text { to } \\
\text { date }\end{array}$ & $\begin{array}{l}\text { Increased opportunities for } \\
\text { direct investment in } \\
\text { processing facilities } \\
\text { including cold chain } \\
\text { solutions and processing } \\
\text { facilities for dairy }\end{array}$ \\
\hline $\begin{array}{l}\text { Women Enterprise } \\
\text { Fund /SNV } \\
(\mathrm{BDA}, 2018)\end{array}$ & 12 Counties & $\begin{array}{ll}\text { Capacity building in } & \text { in } \\
\text { entrepreneurial skills } & \text { in } \\
\text { camel milk value chain } & \end{array}$ & $\begin{array}{l}2016- \\
2020\end{array}$ & $\begin{array}{l}\text { Increase decision-making } \\
\text { power of } 20,000 \text { women }\end{array}$ \\
\hline $\begin{array}{l}\text { USAID multi- } \\
\text { sectorial } \\
\text { collaborations } \\
\text { fostering public- } \\
\text { private partnerships } \\
\text { (USAID, 2019) }\end{array}$ & $\begin{array}{l}\text { Garissa under REGAL-IR } \\
\text { program } \\
\text { Isiolo, Turkana, Nakuru, } \\
\text { Nyeri, Nyahururu, Nandi, } \\
\text { Kericho, Laikipia, and } \\
\text { Embu under Kenya Feed } \\
\text { the Future Innovation } \\
\text { engine (KFIE) program } \\
\text { Marsabit, Wajir Garissa, } \\
\text { Isiolo, Turkana under } \\
\text { Accelerated value chain } \\
\text { development- livestock } \\
\text { component (AVCD-LC) } \\
\text { (ILRI) }\end{array}$ & $\begin{array}{l}\text { Financial facilitation to } \\
\text { purchase aluminum cans, } \\
\text { cooling fridges, and } \\
\text { capacity building in milk } \\
\text { production, hygiene, value } \\
\text { addition and business skills } \\
\text { Innovative livestock } \\
\text { identification and } \\
\text { traceability mechanisms }\end{array}$ & $\begin{array}{l}2012- \\
2017\end{array}$ & $\begin{array}{l}\text { Enhanced resilience of the } \\
\text { community through } \\
\text { increased incomes and } \\
\text { decision-making power in } \\
\text { households and } \\
\text { communities } \\
\text { Strengthening of the } \\
\text { drylands economy } \\
\text { Improved breeding and } \\
\text { animal/herd performance } \\
\text { recording to } \\
\text { Improved accessibility to } \\
\text { insurance and credit } \\
\text { Improved access to regional } \\
\text { and global market } \\
\text { opportunities. } \\
\text { Improved market } \\
\text { information dissemination } \\
\text { and business linkages } \\
\text { aimed at increasing } \\
\text { livestock trade and } \\
\text { resilience of communities } \\
\text { living in the ASAL regions. }\end{array}$ \\
\hline $\begin{array}{l}\text { DFID/Mercy Corps } \\
\text { (BRACE, 2018) }\end{array}$ & $\begin{array}{l}\text { Hadado, Wajir BRACED } \\
\text { program }\end{array}$ & $\begin{array}{l}\text { Purchase of refrigerators } \\
\text { and a van }\end{array}$ & & $\begin{array}{l}\text { Improve livelihoods of } 50 \\
\text { female traders }\end{array}$ \\
\hline
\end{tabular}

\subsection{Opportunities for business to youth and women}

The ASALs of Kenya have been reported to suffer high levels of youth unemployment which renders them vulnerable to radicalization, involvement in cattle rustling and other social perils. Furthermore, women and other vulnerable groups are marginalized during decision making processes in ASALs (GoK, 2017).

The accelerated involvement of Kenyan youth and women in agribusiness and agricultural product value chains will certainly contribute to increased youth employment, food security (Osti et al, 2015) and by extension contribute to meeting the Sustainable Development Goals (SDGs), including ending extreme poverty, zero hunger and gender equality.

Considering the ASALs cover $89 \%$ of the country's landmass, the national and county governments should consider investing in youth through a commitment to providing financial support, including increased spending on youths' initiatives along agricultural product value chains. The Youth enterprise development fund (YEDF) gazetted in 2006 has since created employment and credit opportunities for the youth. It has been described by Kimando and others (2012) that for the YEDF to succeed, the youth enterprise owners need to be equipped with both short and long term skills in entrepreneurship, business planning and financial management and be well conversant with their business interest for their business ventures to be sustainable. It has also been suggested that provided with skills such as credit management, entrepreneurship and business management, as well as livestock production and camel milk sanitation skills offered at vocational and technical training institutions will greatly prepare the youth and women to start and management business in the camel milk value chain as well as other chains. Furthermore, linking the women and youth to Sharia-compliant financial institutions will enhance access to financial services and enable members to open bank accounts.

Entrepreneurial opportunities for the youth and women in the camel milk value chains include, breeding of dairy 
camel breeds, fodder production, establishing camel milk bulking points and cooling centres, processing of camel milk and value addition to develop an assortment of innovative products, provision of cold-chain transportation as well as export of camel milk

\subsection{Recommendation and way forward}

7.1 Potential for commercialization of camel milk in Kenya

Musinga et al, 2008 revealed that the emergence of commercial camel milk industry in Kenya has been attributed to the influx of camel keeping communities, mainly the Somalis. UNHCR, 2014 documented that after political crisis in Somalia during 1991-1992 and 2007-2009 Kenya has received Somali refugees to the tune of 400,000. As traditional consumers of camel milk living in urban Kenya away from their camel herds, it is argued that it is this influx of camel milk consumers that has created a significant rise in the demand for camel milk in Nairobi which triggered commercialization of the industry. It could therefore be argued that the commercial camel milk industry in Kenya is relatively young at around 28 years old.

The major factor affecting camel milk yield is its genetic potential (Musinga et al, 2008). In comparison to successful camel dairy research in Israel, UAE, Saudi Arabia that produce 30-40 litres of milk daily, Kenyan dromedaries highest milk producing breed like Somali breed has average daily yield of 6 litres. Kenyan camel breeds have not been selected for milk production and have a great potential to be exploited genetically in a bid to establish commercial camel production hubs across the ASALs. Genetic breeding should therefore be a key research priority in Kenya.

\subsection{Way forward}

With the camel milk value chains already identified and mapped, the commercialization of production hubs across the ASALs, bulking points, cold storage hubs and camel milk transport services should be supported and capacity built to provide such services.

The review found milk contamination to be a common and a major factor hindering milk marketing from pastoral areas. Sub-clinical mastitis is a big challenge in camel milk production. Milk quality and infection testing is not a common practice among the camel keepers. This is despite the fact that the California Mastitis Test (CMT) is an easy test to administer and the technology has been taught to the camel keepers.

This review recommends that the County governments in the ASALs should foster public-private partnerships with the rural dairy self-help groups and cooperatives to facilitate vertical and horizontal linkages across the camel milk chain; to develop entrepreneurial skills through trainings; to create linkages between producers, traders, veterinary service and consumers, promote camel milk value addition and facilitate financial access by linking the self-help groups and cooperatives to identified financial institutions.
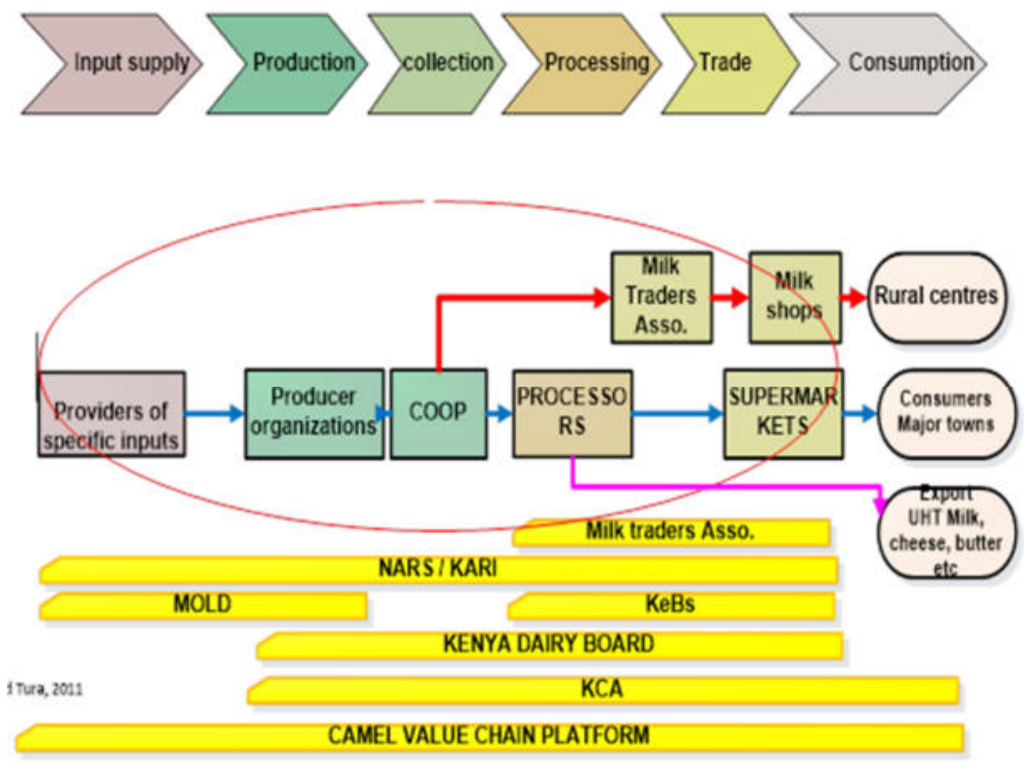

Figure 8: Futuristic camel dairy value chain map Source: Tura et al, 2011

Markets and trade in ASALs need to be supported to reduce losses of livestock and livestock products as a result of climatic factors, by the provision and accessibility to water points and establishment and provision of fodder. 
The availability of permanent rivers like Tana, Ewaso Nyiro and Daua rivers provide good opportunity for provision of water and fodder for camels and other livestock. However, the growth of invasive riverine species like Propopsis juliflora has a negative impact on camel milk production. It makes it difficult for camels to have access to drinking water. To enhance sustainable high milk yielding breeds of camels, there is need to have long term breeding programmes while the camel keepers are trained on good breeding practices. There is need to register Kenya camel breeds with Kenya studbooks and formation of Kenyan camel breeders' association (KCBA).

\section{References}

Abdoun KA, Amin ASA, Abdelatif AM. Milk composition of Dromedary camels (Camelus dromedarius): nutritional effect and correlation to corresponding blood parameters. Pakistan Journal of Biological Sciences. 2007; 10:2724-7.

Agriconsortium 2003. Livestock and Livestock Products Production and Marketing System in Kenya. Draft Final Report. Agrisystems Limited. European Commission, Nairobi Kenya.

AL-Ayadhi Laila Y. Camel Milk as a Potential Therapy as an Antioxidant in Autism Spectrum Disorder (ASD) Evidence-Based Complementary and Alternative Medicine. 2013:8. Article ID: 602834.

AU-IBAR (African Union Interafrican Bureau For Animal Resources). 2017. Dromedary Camel (Camelus dromedarius) Ship of the desert. www.au-ibar.org/component/jdownloads/finish/129/2977.

Baringo (CG) County Government. 2013. First County Integrated Development Plan: 2013-2017. August 2013.

BDA (Business Daily Africa) 2018. www.businessdailyafrica.com NGO to train women in agriculture, renewable energy entrepreneurship Sunday, October 9, 2016 16:23

Behnke, R. and Muthami, D. 2011. The Contribution of Livestock to the Kenyan Economy. Odessa Centre, Great Wolford. United Kingdom and Kenyan National Bureau of Statistics. Nairobi, Kenya. IGAD Livestock Policy Initiative.IGAD LPI Working Paper No. 03 - 11 September 21, 2011.

CAMASEPRO (Camel manual for Service Providers). 2012. Kenya Camel Association.

Ehlayel MS. Camel milk: an alternative for cow's milk allergy in children. Allergy Asthma Proc. 2011;32(3):255-8. doi: 10.2500/aap.2011.32.3429

FAO (Food and Agriculture Organization of the United nations). 2019. Data accessed in 1st May 2019. http://www.fao.org/faostat/en/\#data

Farah $Z$ and Fischer A. 2004. Milk and meat from the camel. Handbook of products and processing, published by ETH Zurich/Singen.

Farah, K.O, Nyariki, D.M, Ngugi, R.K, Noor, I.M and Guliye, A.Y 2004. The Somali and the camel: Ecology, management and economics. College of Agriculture and Veterinary Sciences (CAVS) University of Nairobi.

Faye B. 2015. Role, distribution and perspective of camel breeding in the third millennium economies. Emir. J. Food Agric. 2015. 27 (4): 318-327.

Faye, B., M. Bengoumi and A. Barkat. 2003. The development of dairy camellin systems peri-urban areas in Africa. Int. Workshop on milk of camel in Africa. . Atelier Int. sur le lait de chamelle en Afrique. FAO-CIRAD- KARKARA, Niamey (Niger), 5-8/11/03, 115- 125.

Garissa CG (County Government). 2018. Second Garissa County Integrated Development Plan: 2018-2022.

GoK (Government of Kenya) 2017. A draft on National Policy for the Sustainable Development of Arid and Semi-Arid Lands 'Unlocking Our Full Potential for the Realization of the Kenya Vision 2030' Ministry of Devolution and ASAL areas.

GoK (Government of Kenya) 2019. Draft National Livestock Policy. Ministry of Agriculture, Livestock, Fisheries and Irrigation State Department for Livestock.

Herren, U.J. 1990. The Commercial Sale of Camel Milk from Pastoral Herds in the Mogadishu Hinterlands, Somalia. Pastoral Development Network Paper No. 30. ODI, London.

Hüelsebusch, C.G., Kaufmann, B.A. (2002). Camel Breeds and Breeding in Northern Kenya - An Account of Local Camel Breeds of Northern Kenya and Camel Breeding Management of Turkana, Rendille, Gabra and Somali Pastoralists. Kenya Agricultural Research Institute, Nairobi, Kenya

Kanuspayeva G, Faye B, Loiseau G. The composition of camel milk: a meta-analysis of the literature data. J Food Compos Anal. 2009;22:95-101.

Kanuspayeva G., (2007). Physicochemical and biochemical variability of the milk of the grandscamélids (Camelus bactrianus, Camelus dromedarius and hybrids) in Kazakhstan. PhD thesis in food science. University of Montpellier II, France.

Khan B.B. Arshad I. and Riaz M. 2003. Production and Management of Camels. University of Agriculture, Faisalabad, Department of Livestock Management.

Khaskheli M, Arain MA, Chaudhry S, Soomro AH, Qureshi TA. Physico-chemical quality of camel milk. J Agri Soci Sci. 2005; 2:164-6.

Kimando, L.N., Njogu G.W., and Kihoro J.M. 2012. Factors Affecting the Success of Youth Enterprise Development Funded Projects in Kenya; A Survey of Kigumo District Muranga County. International Journal of Business and Commerce. Vol. 1 No. 10.

Knoll Eva-Maria and Burger Pamela, editors. Camels in Asia and North Africa: Interdisciplinary Perspectives on Their Past and Present Significance. Vol. 18, Austrian Academy of Sciences Press, 2012, www.jstor.org/stable/j.ctt3fgkpz

Laikipia CG (County Government). 2018. Second County integrated development plan 2018-2022.

Mandera CG (County Government). 2018. County annual development plan (2019-2020). August 2018.

Marsabit CG (County Government). 2018. Second county integrated development plan 2018-2022.

Mona E. Biochemical Effects of Fermented Camel Milk on Diarrhea in Rats. New York Science Journal. 2010;3(5):106-11.

Musinga M, Kimenye D and Kivolonzi P. (2008). The camel milk industry in Kenya. Final report commissioned by SNV/RMC 
to explore the potential of Camel Milk from Isiolo District to access sustainable formal markets.

Muloi D., Alarcon P., Ombuia J., Ngeiywa K.J ,Abdullahi B., Muinde P., Karani M.K., Rushton J., and Fèvr E.M. 2018. Value chain analysis and sanitary risks of the camel milk system supplying Nairobi city, Kenya. Preventive veterinary Medicine, 159 (2018) 203 - 210.

NMG (Nation Media Group) 2013. https://www.nation.co.ke Government rolls out programme to give camels to pastoralists. Wednesday December 11, 2013

Noor I.M., 2013. Characteristics, feeding and marketing practices of the emerging peri-urban camel production system in isiolo county, Kenya.

Noor, I.M., Guliye A.Y., Tariq M., and Bebe B.O. 2013. Assessment of camel and camel milk marketing practices in an emerging peri-urban production system in Isiolo County, Kenya. Pastoralism Research, Policy and Practice. 2013, 3:28.

Nyamori B, F Wayua, G Buke and H Walaga. 2005. Quality of marketed milk in the arid and semi arid lands of Kenya. In the KARI Marsabit Annual Report, 2005.

Omar A. A. and Hamad A.A. Compositional, technological and nutritional aspects of dromedary camel milk. International Dairy Journal. 2010; 20:811-21. doi: 10.1016/j.idairyj.2010.04.003

Osti A., van Land J., Magwegwe D., Peereboom A., van Oord J. and Dusart T. 2015. The future of youth in agricultural value chains in Ethiopia and Kenya. http://www.fairandsustainable.nl/wp-content/uploads/2015/11/REPORT

Samburu CG (County Government). 2013. Samburu County Integrated Development Plan 2013-2017.

Shabo Y and Yagil R. Etiology of autism and camel milk as therapy. Journal of Endocrine Genetics. 2005;4(2):67-70.

Shamsia SM. Nutritional and therapeutic properties of camel and human milks. International Journal of Genetics and Molecular Biology. 2009; 1(2):52-8.

Simpkin, S.P., Rowlinson, P., Tullu, D. and Lesorogol, P. 1996. A comparison of two traditional camel calf management systems in Kenya and their implications for milk production. In: Proceedings of the International Conference on: Camelids: Science and productivity, December 15-19, 1996. Eilat, Israel, Journal of Camel Practice and Research, 4:229-234.

Simpkin S.P. 1998. The effects of breed and management on milk yield of camels in Ker PhD thesis, University of Newcastleupon-tyne.

Standard 2018. The Standard newspaper, August 15th 2018. Camels of Kerio ease hardships https://www.standardmedia.co.ke/article/2001291933/

Tura I. and Hussein W., 2015. Camel production on Mount Marsabit: Opportunities, challenges and future prospects. Kenya Agricultural and Livestock Research Institute (KALRO) Technical report, June 2015.

Tura et al 2011. Camel product value chain upgrading strategies. Proceedings of a Stakeholder's Workshop In Garissa Kenya, March 2011.

Turkana CG (County Government). 2013. County Integrated Development Plan 2013-2017.

Wajir CG (County Government). 2015. Wajir County Annual Development Plan 2015/2016.

West Pokot CG (County Government). 2018. West Pokot County Integrated Development Plan 2018-2022.

UNDP (UN Development Programme) (2005) 'Kenya National Disaster Profile'. Nairobi: UNDP.

Elhadi Yazan A.M and Wasonga Oliver V. 2015. Economic and nutritional contribution of camel milk in Northern Kenya: A field study in Isiolo County. Country Report May 2015. IIED Country Report. IIED, London. http://pubs.iied.org/10125IIED.

USAID (US Agency for International Development and USGS (US Geological Survey) (2010). 'A Climate Trend Analysis of Kenya: August 2010'. FEWS NET Informing Climate Change Adaptation Series. Washington, DC: USAID

Yagil Reuven. Camels and camel milk book. Food and Agriculture Organization of the United Nations; pp. 17-18. Available from: http://afghanag.ucdavis.edu/c_livestock/camels/Man_Live_Camel_Milk_FAO.pdf

Yagil Reuven., DVM camel milk and its unique anti-diarrheal Properties. $\overline{I M A J} .20 \overline{0} 13: 1 \overline{5}$.

Zibaee S., Hosseini S.M., Yousefi M., Taghipour A., Kiani M.A. and Noras M.R. 2015. Nutritional and Therapeutic Characteristics of Camel Milk in Children: A Systematic Review. Electron Physician. 2015 Nov; 7(7): 1523-1528. 